\title{
Early Professional Orientation of Students: Interaction Mechanisms of HEI and Industrial Undertakings
}

\author{
Taras V. Kustov ${ }^{1}$, Irina I. Zhuravleva ${ }^{2}$ \\ Saint Petersburg Electrotechnical University "LETI" \\ St. Petersburg, Russian Federation \\ tvkustov@etu.ru, ${ }^{2}$ kurki87@mail.ru
}

\author{
Olga N. Markova, Valentina M. Pukhova ${ }^{3}$ \\ Saint Petersburg Electrotechnical University "LETI" \\ St. Petersburg, Russian Federation \\ 3 vmpukhova@etu.ru
}

\begin{abstract}
Mechanisms of early professional orientation of students such as educational and on-site trainings, internships at high-tech enterprises, guided visits and presentations of enterprises, job fairs and career days are considered.
\end{abstract}

Keywords - career; early professional orientation; interaction mechanisms; HEI; industrial enterprises; engineering personnel

\section{INTRODUCTION}

Currently, a system formation process of engineering personnel trainings for modern industrial enterprises is active in Russia. Today, engineering personnel are understood as not simply university graduates, but unique specialists with general cultural and professional competencies, which are necessary to perform specific production functions that meet modern professional standards. In a gradual convergence of educational and professional standards, the modern system of engineering personnel trainings is characterized by the multi-level trainings, multivariate educational approaches, strengthening of a role played by employers in engineering personnel trainings, increasing practical orientation level of higher education programs, high standards for the state accreditation of HEI education programs, conditions creation for professional and international accreditations of education programs, organization of federal and regional centers for graduates and working professionals competences evaluations [1].

At the same time, almost all employers, especially representatives of large Russian high-tech enterprises of the electronic profile, which participated in the importance assessment of professional competencies when developing the Federal State Educational Standards of new generation, prefer graduates with advanced fundamental and general education. The fundamental professional and appropriate special education under rapidly changing priorities in science and technology, and, as a result, under rapidly changing product ranges in industrial production, directly affects the independent and fast acquisition of the necessary new knowledge by graduates, quick adaptation of the graduates to new specific types of professional activity and, ultimately, their successful professional careers [2].

The successful professional careers of HEI graduates in their direction (specialty) of trainings are the main and natural assessment criterion of graduates trainings quality by employers. In this regard, it is reasonable to start the graduate professional career while educational process and not after the graduation. Many industrial undertakings realize the importance of their direct participation in new engineering personnel trainings and provide this opportunity. Let us consider interaction mechanisms of HEI and industrial undertakings in a context of an early professional employment of students.

\section{TRAININGS OF STUDENTS AT ENTERPRISES}

The most important cooperation part between HEI and industrial undertakings is on-site training of students, and thus, the interaction system organization of HEI and main trainings bases, which are enterprises where students are allowed to work in accordance with their direction of trainings. An agreement on students on-site trainings should be signed up between the HEI and enterprise. The HEI unit, which is responsible for the students on-site trainings organization, develops the trainings plan and individual tasks, while the enterprise negotiates these documents and provides on-site training places. Together, the HEI and enterprise make a trainings schedule. This is the most traditional interaction mechanism, but it is still relevant. On-site trainings at enterprises eliminate a contradiction between HEI traditional trainings and students interests. This partnership scheme is beneficial for everyone: the enterprise, which allows students to work during trainings, has an opportunity to see undergraduates at work, and the HEI, to a certain extent, fills the gap in existing trainings. At ETU "LETI", for example, about $90 \%$ of students who are citizens of the Russian Federation conduct trainings at regional enterprises. Unfortunately, enterprises often cannot provide this opportunity for citizens of other countries.

\section{INTERNSHIPS}

In contrast to trainings, internships are not an integral part of the education process. Enterprises hire interns as ordinary employees. However, interns working schedule may differ from that established in organization, it can be either flexible or part-time, which is convenient, for example, for master's degree students. As a general rule, enterprises provide students with internships for some merits: winning the competition, etc., since the internship is one of the types of additional professional education of specialists and it is carried out to form and practically consolidate professional knowledge and 
skills acquired as a result of theoretical trainings. Internship may be paid.

\section{COURSE PROJECTS AND THESIS PREPARATIONS}

On the one hand, course projects and thesis preparation are one of the forms of students research work, and on the other, thesis preparation should be considered inextricably connected with the organization of pre-degree practical trainings. Therefore, bachelor's or master's thesis preparation at the enterprise meets this enterprise interests and becomes a good motivation to continue this work. The enterprise also has time and opportunity to evaluate this candidate for a vacant position, and to get an idea of the training level at the HEI in general.

\section{GUIDED VISITS AND PRESENTATIONS OF ENTERPRISES}

At the very beginning of acquaintance with a field of professional activity that students have chosen for themselves, it is important to engage them and show development prospects of the industry where they can apply their professional skills. The regular guided visits to the city enterprises within the social partnership framework can be considered as the first stage of the students professional orientation, which forms a positive time perspective related to their future profession [3].

The presentations of enterprises are also of great interest to students, especially if the target audience is correctly selected, so that the direction of students trainings is consistent with the enterprise working direction. For example, at ETU "LETI" more than 20 guided visits and presentations of various companies are held annually. The following companies and enterprises are the most successful among students: JSC Alfa Bank, Group of Companies "Diakont", LLC Titan Engineering, Group of Companies "TwinPro", NRC "Kurchatov Institute", JSC Oceanpribor, JSC "RRI" Electronstandart", State Unitary Enterprise "TEK SPb", JSC Ravenstvo, JSC Compressor, RAIDIX, PJSC MTS, Group of Companies "Rakurs", CJSC Rielta, Business Incubator "Ingria", JSC Technopark of Saint Petersburg, Special Design Bureau "Kontur", Procter \& Gamble, LLC Doctor Web, Elmos Semiconductor AG, JSC NII TM, JSC Coulon, JSC "VNIITVCH", Webim and others.

\section{JOB FAIRS HOLDING}

Job fairs unite interests of employers, HEI and graduates. In recent years, not only graduates, but also undergraduate students, attend job fairs and career days at HEI. For participation in such events, HEI must select enterprises that provide better working conditions, namely the regional market leaders in the directions of HEI trainings. At job fairs, human resources department representatives of potential employers conduct interviews, advice students on available job opportunities, and offer graduates places for on-site and predegree practical trainings. Job fairs remain one of the most important directions in strengthening partnerships with employers.

Job fairs that are held in the interests of one partner also have a good effect. Thus, for 4 years in a row, ETU "LETI" has held job fairs for PJSC Gazprom. In 2019, 17 subsidiaries of
PJSC Gazprom offered job opportunities and places for trainings for students and graduates of ETU "LETI".

\section{CREATION OF JOB PORTALS}

The above mentioned interaction mechanisms require an information support such as the HEI own job portals, posting on the HEI website information about enterprises that are regional market leaders, etc. The job portal at ETU "LETI" was launched in 2016. The job portal purposes are to increase the graduates competitiveness in the labor market, implement the "Early professional employment" program for ETU "LETI" students, and increase the HEI attractiveness. The job portal creation necessity was due to the change of methodology for calculating of the indicator "Employment of graduates" in 2016 according to instructions of the Ministry of Education and Science (based on the Pension Fund of the Russian Federation data). The main objectives of the job portal are listed below:

- Creation of the modern service of employment opportunities that is convenient for students and industrial partners of the HEI

- Modernization of systems of students trainings and graduates employment

- Increasing the number of partners for trainings and graduates employment

- Carrying out regular activities aimed at stimulating graduates employment

After three years, the job portal has proven its relevance. 22 specialized enterprises, which have working direction consistent with directions of students trainings of the HEI, are constantly presented on the job portal. The benefits are listed below.

\section{For enterprises}

- Selection of employees not only in the interests of large enterprises, but also in the interests of small and medium-sized businesses

- Selection of highly qualified personnel in the particular technical field

- Ability to recruit employees on-line and save time

- Selection possibility through trainings and internships at enterprises

- Availability of relevant labor market information in the particular technical field

\section{For students}

- Selection of vacancies in the direction of training online

- Possibility to find a place for on-site trainings

- Possibility to find a future employer before graduation

- Review of the specialized enterprises of the region 
- Understanding individual chances and value in the labor market

- Establishing professional contacts

For HEI

- Possibility of internal monitoring of graduates employment

- Possibility to monitor demands for trainings directions in the labor market to quickly adapt education programs to the employers needs

- Attraction of applicants, as well as the formation of the competitive situation

- Ability for foreign graduates to use the job portal to maintain professional contacts

- Ability to create international and Russian associations of the HEI graduates based on the professional community

\section{ROLE OF UNITS OF PROFESSIONAL ORIENTATION AND EMPLOYMENT}

The HEI units of professional orientation and employment are in constant contact with industrial enterprises to implement interaction mechanisms. They find a balance between interests of departments and industrial enterprises. The interests of higher educational institutions are to increase their competitiveness in the educational services and scientific products market by improving the quality of graduates professional trainings and teaching personnel advanced trainings. The interests of enterprises are to increase the competitiveness of their products and services by improving the quality of personnel. However, in the process of interaction between HEI and enterprises there is a third party, namely students and graduates, since the quality of professional trainings determines their competitiveness and relevance in the professional labor market. Therefore, at the HEI units of professional orientation and employment it is necessary to have employees familiar with the HEI educational programs and working direction of the specialized enterprises.

\section{CONCLUSION}

The steady trend of an early professional employment exists today within the framework of strategic cooperation between the HEI and industrial enterprises. Students themselves tend to get professional orientation earlier, and try to get information about the labor market as soon as possible. The enterprises, which are interested in new personnel, are also ready to participate in the process of young specialist formation and trainings in accordance with their needs. The developed mechanisms allow providing industrial enterprises not only with qualified, but also with professionally adapted personnel.

\section{REFERENCES}

[1] Danilov A. N., Gitman M.B., Stolbov V. Yu., Gitman E. K. Sistema podgotovki inzhenernykh kadrov v sovremennoy Rossii: obrazovatel'nye traektorii $i$ kontrol' kachestva. [Engineering Personnel Training System in Modern Russia: Educational Trajectories and Quality Control]. Higher education in Russia. Vol.27(3), 2018. P. 5-15. (In Russian)

[2] Yankevich V.B. Uchastie rabotodateley $v$ otsenke kachestva podgotovki vypusknikov i problemy ikh trudoustroystva.[Participation of employers in assessing the quality of graduates trainings and problems of their employment]. XIV Russian Scientific and Practical Conference on Planning and Teaching Engineering Staff for the Industrial and Economic Complex of the Region. Saint Petersburg, 2014. P. 91-95. (In Russian)

[3] Batrak L.V., Vasil'ev D.Yu., Pokhovtseva G.P. Ekskursii na predpriyatiya goroda kak forma adaptatsii budushchikh spetsialistov. [Guided visits to the city enterprises as a form of orientation of future specialists]. Education. Career. Society. Vol.3 (42), 2014. (In Russian) 